\title{
Treatment of neonatal abstinence syndrome
}

\author{
K Johnson, C Gerada, A Greenough
}

Arch Dis Child Fetal Neonatal Ed 2003;88:F2-F5

Neonatal abstinence syndrome (NAS) is suffered by infants withdrawing from substances on which they have become physically dependent after in utero exposure. They may require prolonged treatment and spend weeks or even months in hospital. A wide range of drugs have been used to treat NAS. The efficacy of few, however, have been adequately investigated. Evidence suggests that opioids are the most appropriate, at least in infants exposed to diamorphine or methadone. In all "head to head" trials, diazepam has been shown to be ineffective. Morphine and methadone are currently the most commonly prescribed opioids to treat NAS, but randomised trials have not been undertaken to determine which is the more beneficial. Many infants with NAS have been exposed to multiple substances in utero. Further research is required into whether a single opiate or a multiple drug regimen is the best option for such patients.

See end of article for authors' affiliations ......................

Correspondence to: Dr Johnson, Department of Child Health, 4th floor, Ruskin Wing, King's College Hospital, London SE5 9RS, UK:

kathryn.2.johnson@kcl.ac.uk

Accepted 27 June 2002

Accepted 27 june 2002
M isuse of a wide variety of substances during pregnancy is common. Anonymous screening of women attending antenatal clinics showed that $11-16 \%$ were taking at least one illicit substance ${ }^{2}$ (table 1). Most women were taking cannabis alone, but this substance may have adverse effects on fetal wellbeing. ${ }^{2}$ In utero exposure to cannabis has been associated with delivery at a significantly earlier gestation and a reduction in birth weight. ${ }^{2}$ The effect on birth weight, however, appears to be less than that resulting from in utero tobacco exposure. Smoking during pregnancy has been associated with a mean reduction in birth weight of $256 \mathrm{~g},{ }^{3}$ whereas meta-analysis of studies examining the effects of cannabis exposure has highlighted that the mean reduction in birth weight in infants of frequent users (at least four times a week) was only 131 g. ${ }^{4}$ It is essential to screen all antenatal women, to obtain an accurate incidence of drug use during pregnancy, as, in one study, ${ }^{5}$ nearly $40 \%$ of pregnant women screened who had positive urine tests for non-prescribed substances denied drug misuse. There are, however, important ethical issues in universal screening that must be considered before adopting such an approach. Infants exposed to certain drugs in utero may become physically dependent on them and after birth suffer withdrawal symptoms, termed the neonatal abstinence syndrome (NAS). NAS is characterised by central nervous system, gastrointestinal, and respiratory dysfunction. Affected infants commonly have irritability, high pitched cry, tremors, hypertonicity, vomiting, diarrhoea, and tachypnoea.

Diamorphine used to be the most common opiate abused in pregnancy, but now it is methadone. ${ }^{6}$ Women enrolled in methadone programmes have been reported to have better antenatal care than those not in such programmes, ${ }^{7-9}$ but methadone rather than diamorphine can cause more severe and prolonged withdrawal in infants with NAS. $^{8-10}$ NAS is often used to describe neonatal opiate withdrawal, but the use of other illicit substances may contribute to the neonate's ill health. Benzodiazepine use can result in withdrawal requiring treatment, and, in one series, ${ }^{11} 50 \%$ of pregnant women abusing opiates were also taking benzodiazepines. Barbiturate use (prescribed and illicit) during pregnancy can also result in withdrawal symptoms sufficiently severe to require treatment. ${ }^{12}{ }^{13}$ One third of methadone users have been reported to take cocaine, ${ }^{14}$ which is known to have significant vasoconstrictive effects on the developing brain, ${ }^{15}$ leading to neurological abnormalities. ${ }^{16}{ }^{17}$ Cocaine use alone does not cause NAS; abstinence scores, however, were significantly higher in infants exposed to both cocaine and diamorphine than in those exposed to diamorphine alone. ${ }^{18}$

Between $30 \%{ }^{19}$ and $80 \%{ }^{20}$ of infants exposed to opiates in utero require treatment for NAS. ${ }^{20}$ Many agents have been used including a variety of opioids, clonidine, chloral hydrate, chlorpromazine, diazepam, and phenobarbitone. A survey of UK practice in $1994^{21}$ highlighted chlorpromazine as the most commonly prescribed agent, being administered in $70.8 \%$ of neonatal units that had prescribing recommendations or policies. Opioids (morphine, methadone, or diamorphine) were prescribed in $10.8 \%$ of units, and phenobarbitone and chloral hydrate in $9.2 \%$ and $7.7 \%$ respectively. Additional agents, most commonly phenobarbitone and morphine, were used, when required in about $50 \%$ of those units. The aim of this review was, by examining the available evidence, to determine whether it was possible to identify the most appropriate treatment for infants suffering from NAS.

\section{PHARMACOLOGICAL ACTIONS OF TREATMENTS USED FOR NAS}

Morphine, diamorphine, and methadone activate opiate receptors in the locus ceruleus, one of the major clusters of noradrenergic cells in the brain. Their action decreases the activity of adenylate cyclase, resulting in a reduction in cAMP production..$^{22}$ As a consequence, potassium efflux is increased and calcium influx into the cell is decreased, resulting in a decrease in noradrenaline (norepinephrine) release. ${ }^{24}$ During chronic opiate use, noradrenaline release gradually increases towards its normal level as tolerance 
Table 1 Illicit substance use in women attending two inner city London antenatal clinics

\begin{tabular}{lll}
\hline & Farkas et al & Sherwood et al \\
\hline Number screened & 1000 & 807 \\
Cannabis & 8.5 & 14.5 \\
Opiates (including methadone) & 1.7 & 1.4 \\
Cocaine & 1.1 & 0.4 \\
One or more illicit substances & 10.6 & 15.6
\end{tabular}

Data are expressed as the percentage of the population in which the substances were detected.

develops. ${ }^{25}$ Once the opiates are withdrawn, there is loss of the inhibitory effect, and a significant increase in noradrenaline release to well above normal levels. ${ }^{26}$ This increase in noradrenergic activity coincides with the appearance of withdrawal symptoms in experimental models. ${ }^{27}$ Administration of opioids results in a reduction in neuronal activity and hence a decrease in withdrawal symptoms. Methadone and morphine have cross dependence and similar receptor effects. There are, however, potential advantages of methadone over morphine. These include better oral bioavailability, as morphine has extensive first pass metabolism, and a longer duration of action. ${ }^{25}{ }^{28}$ Clonidine also has inhibitory effects on noradrenaline release in the locus ceruleus, as it is an $\alpha_{2}$ adrenoceptor agonist. Rats treated with clonidine before the induction of opiate withdrawal had less severe withdrawal signs. ${ }^{26}$

Sedative agents such as chloral hydrate, chlorpromazine, diazepam, and phenobarbitone have also been used to treat infants with NAS. They act non-specifically to reduce the manifestations of NAS. Chloral hydrate exerts an hypnotic effect through its active metabolite trichloroethanol. Although some neonatologists have used choral hydrate as a first line treatment for NAS infants, ${ }^{21}$ there is no published evidence to support such a policy. Chlorpromazine is a neuroleptic which acts on the hypothalamus and brainstem. Benzodiazepines have a variety of effects, but in NAS they are given for their sedative action, which results from binding to the inhibitory $\gamma$ aminobutyric acid (GABA) receptor complex in the brain. ${ }^{2528}$ Phenobarbitone is a central nervous system depressant and also acts on the GABA receptor complex, but it has a less specific effect on the brain than diazepam. ${ }^{25} 2829$

\section{CLINICAL EVIDENCE}

\section{Anecdotal series}

Control of symptoms was reported in six of the seven infants treated with clonidine exposed to methadone antenatally, and no toxic effects were observed. ${ }^{30}$ Retrospective comparison of those infants with a cohort treated with phenobarbitone showed that the length of treatment was significantly shorter in the clonidine treated group. Diazepam administration controlled symptoms within 72 hours without any reported adverse effects in 18 infants who had been exposed in utero to diamorphine. ${ }^{31}$

\section{Placebo controlled trials}

There are none.

\section{Treatment comparison}

Non-randomised and randomised comparison trials have been undertaken, but the method of randomisation has not been described in any of the studies (table 2). A variety of outcome measures have been used.

\section{Sucking}

The impact of treatment on sucking has been investigated in three non-randomised trials. ${ }^{32-34}$ Sucking rate is depressed in infants of drug dependent mothers; this effect is more pronounced in infants exposed antenatally to methadone. ${ }^{34}$ Paregoric (an opiate preparation) was reported to be more effective than either phenobarbitone or diazepam in restoring a normal sucking pattern. ${ }^{32-34}$ Treatment with diazepam resulted in a sucking pattern that was less effective than that seen in untreated NAS infants.

\section{Seizures}

The results of a non-randomised study which included 56 withdrawing infants suggested that chlorpromazine was less efficacious in controlling seizures than methadone; 14 of the 44 infants treated with chlorpromazine developed seizures compared with none of the 12 treated with methadone. ${ }^{35}$ Other non-randomised trials have suggested that paregoric ${ }^{36}$ and tincture of opium ${ }^{8}$ may be more effective than diazepam in preventing seizures associated with NAS. ${ }^{36}$ Only one randomised study examining which treatment most effectively controlled seizures in NAS has been reported; paregoric was more effective than phenobarbitone. ${ }^{37}$

\section{Control of NAS symptoms}

In a non-randomised trial, morphine was found to be more effective than combined treatment with phenobarbitone and diazepam. ${ }^{38}$ Chlorpromazine and phenobarbitone may have similar efficacy in controlling symptoms, ${ }^{39}$ as no statistically significant difference in tremor and irritability, assessed by clinical observation, was found between two groups of infants so treated. Symptom control and the influence of treatment on longer term development has only been addressed in one randomised trial, in which the efficacy of paregoric, phenobarbitone, and diazepam were compared.$^{40}$ Paregoric was found to be the most effective agent: all the infants who received diazepam and approximately half of those who received phenobarbitone required a second agent to control their symptoms. No difference, however, was found at six months in the Bayley scale of mental development score between the three groups. ${ }^{40}$

\section{Duration of treatment}

Two randomised studies have been undertaken. In one, ${ }^{41}$ phenobarbitone was associated with a shorter duration of treatment than paregoric, in the other ${ }^{42}$ there were no statistically significant differences in treatment duration between infants prescribed methadone, phenobarbitone, or diazepam.

\section{TREATMENT OF INFANTS WITH POLYDRUG EXPOSURE}

Paregoric was shown to be more effective than phenobarbitone or diazepam in controlling symptoms in opiate exposed infants in two randomised trials. ${ }^{43}{ }^{44}$ In both those trials, however, phenobarbitone was the most effective treatment for infants exposed to polydrugs. ${ }^{43}{ }^{44}$ The results of a recently published study ${ }^{45}$ suggest that a combination of agents may be better treatment for the NAS suffered by infants exposed to multiple drugs in utero. Phenobarbitone given with diluted tincture of opium compared with diluted tincture of opium alone was associated with a shorter hospital stay required for NAS treatment, and hence the hospital cost per patient was reduced by $\$ 35000$. The study, however, was only partially randomised, and the total sample examined was 20 .

\section{ADVERSE EFFECTS OF DRUGS USED TO TREAT NAS}

Side effects of opioids include respiratory depression, which results from a decrease in the sensitivity of brainstem chemoreceptors to carbon dioxide $\left(\mathrm{CO}_{2}\right) .{ }^{28}{ }^{29}$ In a randomised study ${ }^{46}$ in which morphine, methadone, and pethidine were compared in children requiring pain relief after an operation, although no patient developed apnoea or hypoventilation that required intervention, methadone administration was associated with the greatest increase in end tidal $\mathrm{CO}_{2}$. In utero exposure to diamorphine is less likely to result in respiratory depression; indeed affected infants have been noted to have increased 
Table 2 Treatment comparison trials

\begin{tabular}{|c|c|c|c|c|c|c|}
\hline Reference & $\begin{array}{l}\text { Type of drug } \\
\text { exposure in utero }\end{array}$ & $\begin{array}{l}\text { No of } \\
\text { infants } \\
\text { examined }\end{array}$ & Treatments & Randomisation & Outcome measure & Results \\
\hline Kron et $a^{\beta 4}$ & Methadone & 26 & $\begin{array}{l}\text { Paregoric/ } \\
\text { phenobarbitone/ } \\
\text { diazepam }\end{array}$ & $\begin{array}{l}\text { Not stated } \\
\text { whether } \\
\text { randomised }\end{array}$ & Sucking & $\begin{array}{l}\text { Average sucking rate } 31.1 \text { sucks } / \mathrm{min} \text { in } \\
\text { paregoric group, } 19.9 \text { sucks } / \mathrm{min} \text { in } \\
\text { phenobarbitone group }(\mathrm{p}<0.05) \text {, and } 39.6 \\
\text { sucks } / \mathrm{min} \text { in control infants. Sucking rate } \\
6.5 \text { sucks } / \mathrm{min} \text { in diazepam group versus } \\
23.8 \text { sucks } / \mathrm{min} \text { in the controls }\end{array}$ \\
\hline $\begin{array}{l}\text { Finnegan et } \\
a^{\beta 2}\end{array}$ & Methadone & 38 & $\begin{array}{l}\text { Paregoric/ } \\
\text { phenobarbitone }\end{array}$ & Not randomised & Sucking & $\begin{array}{l}\text { Average sucking rate } 29.0 \text { sucks } / \mathrm{min} \text { in the } \\
\text { paregoric treated, } 24.1 \text { sucks } / \mathrm{min} \text { in the } \\
\text { phenobarbitone treated infants }\end{array}$ \\
\hline Kron et $a^{\beta 3}$ & $\begin{array}{l}\text { Diamorphine/ } \\
\text { methadone }\end{array}$ & 42 & $\begin{array}{l}\text { Paregoric/ } \\
\text { phenobarbitone/ } \\
\text { diazepam }\end{array}$ & $\begin{array}{l}\text { Not stated } \\
\text { whether } \\
\text { randomised }\end{array}$ & Sucking & $\begin{array}{l}\text { Average sucking rate } 30.5 \text { sucks } / \mathrm{min} \text { in the } \\
\text { paregoric group }(n=5), 19.4 \text { sucks/min in } \\
\text { the phenobarbitone group ( } n=28), 18.4 \\
\text { sucks/min in the diazepam group }(n=6) \text {, and } \\
23.2 \text { in the controls }(n=8)\end{array}$ \\
\hline $\begin{array}{l}\text { Herzlinger et } \\
a^{\beta 6}\end{array}$ & $\begin{array}{l}\text { Diamorphine/ } \\
\text { methadone }\end{array}$ & 65 & Paregoric/diazepam & Not randomised & Seizures & $\begin{array}{l}\text { Two of } 48 \text { paregoric treated infants and } 5 \text { of } \\
12 \text { diazepam treated infants had seizures } \\
(p<0.01)\end{array}$ \\
\hline $\begin{array}{l}\text { Kandall et } \\
a^{\beta}\end{array}$ & $\begin{array}{l}\text { Diamorphine/ } \\
\text { methadone }\end{array}$ & 132 & $\begin{array}{l}\text { Tincture of } \\
\text { opium/diazepam }\end{array}$ & Not stated & Seizures & $\begin{array}{l}\text { More convulsions seen in infants treated with } \\
\text { diazepam }(p<0.01)\end{array}$ \\
\hline $\begin{array}{l}\text { Kandall et } \\
a^{\beta 8}\end{array}$ & Methadone & 111 & $\begin{array}{l}\text { Paregoric/ } \\
\text { phenobarbitone }\end{array}$ & $\begin{array}{l}\text { Randomisation } \\
\text { method not } \\
\text { stated }\end{array}$ & Seizures & $\begin{array}{l}\text { No infant had seizures in the paregoric } \\
\text { group, } 7 \text { of } 62 \text { infants in the phenobarbitone } \\
\text { group had seizures }(p<0.025)\end{array}$ \\
\hline $\begin{array}{l}\text { Pacifico et } \\
a^{\beta^{7}}\end{array}$ & Diamorphine & 25 & $\begin{array}{l}\text { Morphine/ } \\
\text { phenobarbitone + } \\
\text { diazepam/morphine } \\
\text { + phenobarbitone + } \\
\text { diazepam }\end{array}$ & Not stated & Symptom control & $\begin{array}{l}\text { Maximum withdrawal score } 35 \text { in the } \\
\text { morphine treated group, } 75 \text { in the } \\
\text { phenobarbitone + diazepam group and } 100 \\
\text { in the phenobarbitone + diazepam + } \\
\text { morphine group }\end{array}$ \\
\hline Kahn et $a^{\beta 9}$ & Diamorphine & 38 & $\begin{array}{l}\text { Phenobarbitone/ } \\
\text { chlorpromazine }\end{array}$ & $\begin{array}{l}\text { Randomisation } \\
\text { method not } \\
\text { stated }\end{array}$ & Symptom control & $\begin{array}{l}\text { There was no significant difference in } \\
\text { symptom control, as assessed by clinical } \\
\text { observation in the } 19 \text { infants treated with } \\
\text { chlorpromazine and the } 19 \text { treated with } \\
\text { phenobarbitone }\end{array}$ \\
\hline $\begin{array}{l}\text { Finnegan et } \\
a^{44}\end{array}$ & Opiate/polydrug & 139 & $\begin{array}{l}\text { Paregoric/ } \\
\text { phenobarbitone/ } \\
\text { diazepam }\end{array}$ & $\begin{array}{l}\text { Randomisation } \\
\text { method not } \\
\text { stated }\end{array}$ & Symptom control & $\begin{array}{l}\text { Opiate exposed group; treatment success (as } \\
\text { assessed by no need for a second } \\
\text { therapeutic agent) } 13 \text { of } 14 \text { paregoric } \\
\text { treated, } 13 \text { of } 26 \text { phenobarbitone treated } \\
\text { and } 0 \text { of } 5 \text { diazepam treated infants. } \\
\text { Polydrug exposed group, treatment success; } \\
11 \text { of } 18 \text { paregoric treated, } 54 \text { of } 61 \\
\text { phenobarbitone treated and } 6 \text { of } 9 \\
\text { diazepam treated infants }\end{array}$ \\
\hline $\begin{array}{l}\text { Finnegan } \\
\text { and Ehrlich }{ }^{43}\end{array}$ & Opiate/polydrug & 300 & $\begin{array}{l}\text { Paregoric/ } \\
\text { phenobarbitone/ } \\
\text { diazepam }\end{array}$ & $\begin{array}{l}\text { Randomisation } \\
\text { method not } \\
\text { stated }\end{array}$ & $\begin{array}{l}\text { Days to symptom } \\
\text { control }\end{array}$ & $\begin{array}{l}\text { Opiate exposed infants, mean days to } \\
\text { symptom control } 4.9 \text { in paregoric treated, } \\
6.7 \text { in phenobarbitone treated and } 9.5 \text { in } \\
\text { diazepam treated infants. } \\
\text { Polydrug exposed: } 3.5 \text { days in the } \\
\text { phenobarbitone treated, } 4.7 \text { in the } \\
\text { diazepam treated and } 7 \text { in the paregoric } \\
\text { treated infants }\end{array}$ \\
\hline $\begin{array}{l}\text { Kaltenbach } \\
\text { and } \\
\text { Finnegan } \\
40\end{array}$ & Methadone & 69 & $\begin{array}{l}\text { Paregoric/ } \\
\text { phenobarbitone/ } \\
\text { diazepam }\end{array}$ & $\begin{array}{l}\text { Randomisation } \\
\text { method not } \\
\text { stated }\end{array}$ & $\begin{array}{l}\text { Symptom control } \\
\text { Developmental } \\
\text { outcome at } 6 \\
\text { months }\end{array}$ & $\begin{array}{l}2 \text { of } 23 \text { paregoric treated, } 11 \text { of } 20 \\
\text { phenobarbitone treated and } 10 \text { of } 10 \\
\text { diazepam treated infants required a second } \\
\text { agent to control symptoms. } \\
\text { No significant difference in the } \\
\text { developmental outcome at } 6 \text { months of the } \\
\text { three groups }\end{array}$ \\
\hline $\begin{array}{l}\text { Madden et } \\
a^{42}\end{array}$ & $\begin{array}{l}\text { Diamorphine/ } \\
\text { methadone }\end{array}$ & 50 & $\begin{array}{l}\text { Methadone/ } \\
\text { phenobarbitone/ } \\
\text { diazepam }\end{array}$ & $\begin{array}{l}\text { Randomisation } \\
\text { method not } \\
\text { stated }\end{array}$ & $\begin{array}{l}\text { Duration of } \\
\text { treatment }\end{array}$ & $\begin{array}{l}\text { Mean treatment duration: } 11.7 \text { days in } \\
\text { methadone treated, } 14.5 \text { days in } \\
\text { phenobarbitone treated and } 10.2 \text { days in } \\
\text { diazepam treated infants }\end{array}$ \\
\hline Carin et $a^{41}$ & Methadone & 31 & $\begin{array}{l}\text { Paregoric/ } \\
\text { phenobarbitone }\end{array}$ & $\begin{array}{l}\text { Randomisation } \\
\text { method not } \\
\text { stated }\end{array}$ & $\begin{array}{l}\text { Duration of } \\
\text { treatment }\end{array}$ & $\begin{array}{l}\text { Mean duration of treatment: } 22 \text { days in } \\
\text { phenobarbitone treated infants, } 17 \text { days in } \\
\text { paregoric treated infants }(p<0.01)\end{array}$ \\
\hline
\end{tabular}

respiratory rates and become hypocarbic. ${ }^{47}$ In addition, prematurely born infants of diamorphine addicted mothers have less respiratory distress syndrome, ${ }^{48}$ which may be explained by accelerated lung maturation. ${ }^{49}$ Opioids can often induce nausea and vomiting, as a result of stimulation of the chemoreceptor trigger zone in the medulla. The use of paregoric is no longer recommended because of the potentially toxic additive substances it contains; these include camphor, ethanol, benzoic acid, and anise oil. Adverse effects of clonidine relate to its $\alpha$ agonist action, which reduces noradrenaline release, leading to a reduction in sympathetic outflow and reduced peripheral resistance, heart rate, cardiac output, and blood pressure. The major adverse effect of chloral hydrate is gastrointestinal irrita- tion. Chlorpromazine use may result in cerebellar dysfunction and haematological problems. ${ }^{50}$ Concerns have been raised about the safety of diazepam use in neonates. The intravenous preparation, which has been given orally in the treatment of NAS, ${ }^{31}$ contains a significant amount of sodium benzoate, a potent bilirubin-albumin uncoupler. ${ }^{51}$ Neonates may also have a poor ability to metabolise and excrete diazepam. ${ }^{52}$ Other adverse effects of diazepam include respiratory depression, hypotonia, reluctance to feed, and an impaired metabolic response to a cold stress. ${ }^{53}$ Withdrawal from diazepam is associated with jitteriness and hypertonia, and, although diazepam will stop most neonatal seizures as least briefly, the drug's anticonvulsant effect is poorly sustained. Phenobarbitone has a low therapeutic 
index, as a consequence it has been recommended that levels should be measured during treatment. ${ }^{50}$ Infants may be excessively sleepy and feed poorly. Other potential disadvantages of phenobarbitone include induction of liver enzymes and a rapid tolerance to its sedative effect..$^{50}$

\section{CONCLUSION}

"The limited evidence available suggests that opioids are the most effective treatment in controlling acute problems related to NAS from in utero opioid exposure"

Few appropriately designed trials have been undertaken to determine the most appropriate treatment for infants suffering from NAS. The limited evidence available suggests that opioids are the most effective treatment in controlling acute problems related to NAS from in utero opioid exposure. Increasingly, however, infants have polydrug exposure, and there is little information on how to treat such patients. Infants with NAS may require months of treatment and suffer problems after discharge. Randomised trials are required to determine which treatment for infants with NAS is associated with the best short and long term outcomes.

\section{ACKNOWLEDGEMENTS}

$\mathrm{KJ}$ is supported by Action on Addiction. We are grateful to Ms Sue Williams for secretarial assistance.

\section{Authors' affiliations}

K Johnson, A Greenough, Children Nationwide Regional Neonatal Intensive Care Centre, Department of Child Health, King's College Hospital, London SE5 9RS, UK

C Gerada, The Hurley Clinic, Kennington Lane, London SE 11 4HJ, UK

\section{REFERENCES}

1 Farkas AG, Colbert DL, Erskine KJ. Anonymous testing for drug abuse in an antenatal population. Br J Obstet Gynaecol 1995; 102:563-4.

2 Sherwood RA, Keating J, Kavvadia V, et al. Substance misuse in early pregnancy and relationship to fetal outcome. Eur J Pediatr 1999;158:488-92

3 Milner AD, Marsh W, Ingram DM, et al. Effects of smoking in pregnancy on neonatal lung function. Arch Dis Child Fetal Neonatal Ed 1999;80:F8-14.

4 English DR, Hulse GK, Milne E, et al. Maternal cannabis use and birthweight: a meta-analysis. Addiction 1997;92:1553-60.

5 Gillogley KM, Evans AT, Hansen RL, et al. The perinatal impact of cocaine, amphetamine, and opiate use detected by universal intrapartum screening. Am J Obstet Gynecol 1990;163:1535-42.

6 Lissauer T, Ghaus K, Rivers RPA. Maternal drug abuse: effects on the child. Current Paediatrics 1994:4:235-9.

7 Edelin KC, Gurganious L, Golar K, et al. Methadone maintenance in pregnancy: consequences to care and outcome. Obstet Gynecol 1988;71:399-404

8 Kandall SR, Albin S, Gartner LM, et al. The narcotic-dependent mother: fetal and neonatal consequences. Early Hum Dev 1977;1:159-69.

9 Wilson GS, Desmond MM, Wait RB. Follow-up of methadone treated and untreated narcotic dependent women and their infants: Health developmental and social implications. J Pediatr 1981;98:716-22.

10 Chasnoff IJ, Landress HJ, Barrett ME. The prevalence of illicit-drug use during pregnancy and discrepancies in mandatory reporting in Pinellas County, Florida. N Engl J Med 1990;322:1202-6.

11 Coghlan D, Milner M, Clarke T, et al. Neonatal abstinence syndrome. Ir Med J 1999;92:232-3.

12 Blumenthal I, Lindsay S. Neonatal barbiturate withdrawal. Postgrad Med J 1977;53:157-8.

13 Desmond MM, Schwanecke RP, Wilson GS, et al. Maternal barbiturate utilization and neonatal withdrawal symptomatology. J Pediatr 1972;80: 190-7.

14 Brown HL, Britton KA, Mahaffey D, et al. Methadone maintenance in pregnancy: a reappraisal. Am J Obstet Gynecol 1998;179:459-63.

15 King TA, Perlman JM, Laptook AR, et al. Neurologic manifestations of in utero cocaine exposure in near term and term infants. Pediatrics 1995;96:259-64.

16 Delaney-Black V, Covington C, Ostrea E, et al. Prenatal cocaine and neonatal outcome: evaluation of dose-response relationship. Pediatrics 1996;98:735-40.

17 Napiorkowski B, Lester BM, Freier MC, et al. Effect of in utero exposure on infant neurobehaviour. Pediatrics 1996;98:71-5

18 Fulroth R, Phillips B, Durand DJ. Perinatal outcome of infants exposed to cocaine and/or heroin in utero. American Journal of Diseases in Children 1989;143:905-10.
19 Strauss ME, Andresko M, Stryker JC, et al. Methadone maintenance during pregnancy: pregnancy, birth and neonate characteristics. Am J Obstet Gynecol 1974; 120:895-900.

20 van Baar AL, Fleury P, Soepatmi S, et al. Neonatal behaviour after drug dependent pregnancy. Arch Dis Child 1989;64:235-40.

21 Morrison CL, Siney C. A survey of the management of neonatal opiate withdrawal in England and Wales. Eur J Pediatr 1996;155:323-6.

22 Beitner DB, Duman RS, Nestler EJ. A novel action of morphine in the rat locus ceruleus: persistent decrease in adenylate cyclase. Mol Pharmacol 1989;35:559-64.

23 Duman RS, Tallman JF, Nestler EJ. Acute and chronic opiate regulation of adenylate-cyclase in brain: specific effects in locus ceruleus. $J$ Pharmacol Exp Ther 1988;246:1033-9.

24 Di Chiara G, North RA. Neurobiology of opiate abuse. Trends Pharmacol Sci 1992;13:185-93.

25 Aghajanian GK. Tolerance of locus ceruleus neurones to morphine and suppression of withdrawal response by clonidine. Nature 1978;276: 186-8.

26 Little PJ, Price RR, Hinton RK, et al. Role of noradrenergic hyperactivity in neonatal opiate abstinence. Drug Alcohol Depend 1996;41:47-54.

27 Rasmussen K, Beitner-Johnson DB, Krystal JH, et al. Opiate withdrawal and the rat locus ceruleus: behavioural, electrophysiological and biochemical correlates. J Neurosci 1990;10:2308-17.

28 Holtzman SG, Sung YF. Pain control with opioid analgesics. In: Brody T, Larner J, Minneman K, eds. Human pharmacology. Chicago: Mosby, 1998:395-407.

29 Rech RH. Drugs used to treat anxieties and other related disorders. In: Brody T, Larner J, Minneman K, eds. Human pharmacology. Chicago: Mosby, 1998:365-71.

30 Hoder EL, Leckman JF, Poulsen J, et al. Clonidine treatment of neonatal narcotic abstinence syndrome. Psychiatry Res 1984;13:243-51.

31 Nathensen G, Golden GS, Litt IF. Diazepam in the management of the neonatal narcotic withdrawal syndrome. Pediatrics 1971;48:523-7.

32 Finnegan LP, Connaughton JF, Kron RE, et al. Neonatal abstinence syndrome: assessment and management. Addict Dis 1975;2:141-58.

33 Kron RE, Litt M, Finnegan LP. Narcotic addiction in the newborn: differences in behavior generated by methadone and heroin. Int J Clin Pharmacol Ther Toxicol 1975;12:63-9.

34 Kron RE, Litt M, Phoenix MD, et al. Neonatal narcotic abstinence: effects of pharmacotherapeutic agents and maternal drug usage on nutritive sucking behavior. J Pediatr 1976;88:637-41.

35 Rivers RPA. Infants of drug addicted mothers. In: Rennie JM, Roberton NRC, eds. Textbook of neonatology. Edinburgh: Churchill Livingston, 1999:443-51.

36 Herzlinger RA, Kandall SR, Vaughan HG. Neonatal seizures associated with narcotic withdrawal. J Pediatr 1977;91:638-41.

37 Pacifico P, Nardelli E, Pantarotto MF. Neonatal heroin withdrawal syndrome: evaluation of different pharmacological treatments. Pharmacol Res 1989;21:63-4.

38 Kandall SR, Doberczak TM, Maver KR, et al. Opiate vs CNS depressant therapy in neonatal drug abstinence syndrome. American Journal of Diseases in Children 1983;137:378-82.

39 Kahn E, Neumann L, Polk GA. The course of the heroin withdrawal syndrome in newborn infants treated with phenobarbital or chlorpromazine. Pediatrics 1969;75:495-500.

40 Kaltenbach K, Finnegan LP. Neonatal abstinence syndrome: pharmacotherapy and developmental outcome. Neurobehav Toxicol Teratol 1986;8:353-5.

41 Carin I, Glass L, Parekh A, et al. Neonatal methadone withdrawal. Effect of two treatment regimens. American Journal of Diseases in Children 1983;137:1166-9.

42 Madden JD, Chappel JN, Zuspan F, et al. Observation and treatment of neonatal narcotic withdrawal. Am J Obstet Gynecol 1977; 127:199201.

43 Finnegan LP, Ehrlich S. Maternal drug abuse during pregnancy: evaluation and pharmacotherapy for neonatal abstinence. Modern Methods in Pharmacology 1990;6:255-63.

44 Finnegan LP, Michael H, Leifer B, et al. An evaluation of neonatal abstinence treatment modalities. NIDA Research Monograph 1984:49:282-8.

45 Coyle MG, Ferguson A, Lagasse L, et al. Diluted tincture of opium (DTO) and phenobarbital versus DTO alone for neonatal opiate withdrawal in term infants. J Pediatr 2002;140:561-4.

46 Hamunen K. Ventilatory effects of morphine, pethidine and methadone in children. Br J Anaesth 1993;70:414-18.

47 Glass L, Rajegowda BK, Kahn EJ, et al. Effect of heroin withdrawal on the respiratory rate and acid-base status in the newborn. N Engl J Med 1972;286:746-8.

48 Glass J, Rajecowda BK, Evans HE. Absence of respiratory distress syndrome in premature infants of heroin-addicted mothers. Lancet 1971; ii:685-6.

49 Taeusch HW, Carson SH, Wang NS, et al. Heroin induction of lung maturation and growth retardation. J Pediatr 1973;82:869-75.

50 American Academy of Pediatrics Committee on Drugs. Neonatal drug withdrawal. Pediatrics 1998;101:1079-88.

51 Schiff D, Chan G, Stern L. Fixed drug combinations and the displacement of bilirubin from albumin. Pediatrics 1971;48:139-41.

52 Morselli PL, Principi N, Tognoni G, et al. Diazepam elimination in premature and full term infants and children. J Perinat Med 1973;1:133-41.

53 Cree JE, Meyer J, Hailey DM. Diazepam in labour: its metabolism and effect on the clinical condition and thermogenesis of the newborn. BM $1973 ; 4: 251-5$ 